OPEN ACCESS

Approved by:

Frontiers in Pediatrics Editorial Office

Frontiers Media SA, Switzerland

*Correspondence:

Abhishek Seth

aseth@bcm.edu

Specialty section:

This article was submitted to

Pediatric Urology,

a section of the journal

Frontiers in Pediatrics

Received: 25 July 2018

Accepted: 27 July 2018

Published: 14 August 2018

Citation:

White JT, Sheth KR, Bilgutay AN, Roth DR, Austin PF, Gonzales ET Jr, Janzen NK, Tu DD, Mittal AG, Koh CJ,

Ryan SL, Jorgez C and Seth A (2018)

Corrigendum: Vesicoamniotic Shunting Improves Outcomes in a

Subset of Prune Belly Syndrome

Patients at a Single Tertiary Center.

Front. Pediatr. 6:229.

doi: 10.3389/fped.2018.00229

\section{Corrigendum: Vesicoamniotic Shunting Improves Outcomes in a Subset of Prune Belly Syndrome Patients at a Single Tertiary Center}

\author{
Jeffrey T. White ${ }^{1,2}$, Kunj R. Sheth ${ }^{1,2}$, Aylin N. Bilgutay ${ }^{3}$, David R. Roth ${ }^{1,2}$, Paul F. Austin ${ }^{1,2}$, \\ Edmond T. Gonzales Jr. ${ }^{1,2}$, Nicolette K. Janzen ${ }^{1,2}$, Duong D. Tu ${ }^{1,2}$, Angela G. Mittal ${ }^{1,2}$, \\ Chester J. Koh ${ }^{1,2}$, Sheila L. Ryan ${ }^{4}$, Carolina Jorgez ${ }^{1}$ and Abhishek Seth ${ }^{1,2 *}$ \\ ${ }^{1}$ Scott Department of Urology, Baylor College of Medicine, Houston, TX, United States, ${ }^{2}$ Division of Urology, Department of \\ Surgery, Texas Children's Hospital, Houston, TX, United States, ${ }^{3}$ Department of Urology, Emory University School of \\ Medicine, Atlanta, GA, United States, ${ }^{4}$ Memorial Hermann Health System, Houston, TX, United States
}

Keywords: prune belly syndrome, triad syndrome, Eagle-Barrett syndrome, prenatal intervention, mortality, renal failure, pulmonary hypoplasia, orchiopexy

\section{A Corrigendum on}

Vesicoamniotic Shunting Improves Outcomes in a Subset of Prune Belly Syndrome Patients at a Single Tertiary Center

by White, J. T., Sheth, K. R., Bilgutay, A. N., Roth, D. R., Austin, P. F., Gonzales, E. T. Jr., et al. (2018). Front. Pediatr. 6:180. doi: 10.3389/fped.2018.00180

An author name was incorrectly spelled as Aylin E. Bilgutay. The correct spelling is Aylin N. Bilgutay. The authors apologize for this error and state that this does not change the scientific conclusions of the article in any way.

The original article has been updated.

Conflict of Interest Statement: The authors declare that the research was conducted in the absence of any commercial or financial relationships that could be construed as a potential conflict of interest.

Copyright ( 2018 White, Sheth, Bilgutay, Roth, Austin, Gonzales, Janzen, Tu, Mittal, Koh, Ryan, Jorgez and Seth. This is an open-access article distributed under the terms of the Creative Commons Attribution License (CC BY). The use, distribution or reproduction in other forums is permitted, provided the original author(s) and the copyright owner(s) are credited and that the original publication in this journal is cited, in accordance with accepted academic practice. No use, distribution or reproduction is permitted which does not comply with these terms. 